\title{
Lower Lochkovian (Lower Devonian) conodonts from Cellon section (Carnic Alps, Austria)
}

\author{
Maria G. Corriga, Carlo Corradini, Hans Peter SChÖnlaub \& Monica Pondrelli
}

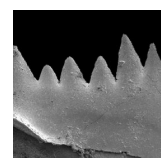

\begin{abstract}
The conodont stratigraphy of the lower Lochkovian part of the famous Cellon section is presented. The association includes twenty-two taxa belonging to nine genera, and allows discriminating the two biozones of the lower Lochkovian (Icr. hesperius and Icr. postwoschmidti zones). Three taxa (Zieglerodina formosa, Z. mashkovae and Z. prosoplatys) are reported for the first time from the Carnic Alps, and other two species of Zieglerodina, probably new, are described in open nomenclature. - Key words: conodonts, biostratigraphy, taxonomy, Lochkovian, Cellon section, Carnic Alps.
\end{abstract}

Corriga, M.G., Corradini, C., SchÖnlaub, H.P. \& Pondrelli, M. 2016. Lower Lochkovian (Lower Devonian) conodonts from Cellon section (Carnic Alps, Austria). Bulletin of Geosciences 91(2), 261-270 (5 figures). Czech Geological Survey, Prague. ISSN 1214-1119. Manuscript received November 19, 2015; accepted in revised form January 28, 2016; published online April 18, 2016; issued June 30, 2016.

Maria G. Corriga \& Carlo Corradini (corresponding author), Dipartimento di Scienze Chimiche e Geologiche, Universitàdi Cagliari, via Trentino 51, I-09129Cagliari, Italy; maria.corriga@unica.it, corradin@ unica.it•Hans Peter Schönlaub, Austrian Academy of Sciences, Commission for Geosciences, Dr. Ignaz Seipel-Platz 2, A-1010 Vienna, Austria; hp.schoenlaub@aon.at • Monica Pondrelli, International Research School of Planetary Sciences, Università d'Annunzio, viale Pindaro 42, I-65127, Pescara, Italy; monica@irsps.unich.it

The Cellon section, located in the central part of the Carnic Alps near Plöckenpass/Passo di Monte Croce Carnico, is one of the most famous sections of the world, exposing rocks from the Katian (Upper Ordovician) to the Lochkovian (Lower Devonian) and, further on along the eastern and western cliff of mountain Cellon to the Lower Carboniferous. It is the reference section for many Silurian studies and is the reference section for the Silurian in the Southern Alps. Many studies focused on the Ordovician and Silurian part of the section, whereas the Lower Devonian have never been investigated in detail, probably because problems of accessibility and the fact that the rocks in the upper part and their fossil content are less spectacular compared to those cropping out in the lower part of the section.

The conodont fauna from the Cellon section was studied and described by Walliser (1964), who illustrated the fauna from the base of the section to just above the Silurian/Devonian boundary. Recently Ferretti \& Schönlaub (2001) revised the biostratigraphy of the Ordovician part of the section, whereas the Silurian part has been updated by Corradini et al. (2015a).

In this paper we describe the conodont fauna from the lowermost Devonian, integrating the younger samples from Walliser (1964) collection, that we studied during a research visit at Göttingen University, with new data from samples picked in the uppermost part of the section, until a steep wall prevented any further sampling.

\section{Geological settings}

The Carnic Alps are located along the Italian-Austrian border (Fig. 1) and exposed rocks deposited between the Middle Ordovician and the Upper Triassic. Three sedimentary sequences are distinguished: the Pre-Variscan, the Permo-Carboniferous and the Alpine. The Pre-Variscan sequence includes rocks of Middle Ordovician to lowermost Pennsylvanian age, which represent one of the better-preserved and continuous sequences of the world. This sequence was affected by the Variscan orogeny during the late Bashkirian and early Moscovian (Schönlaub 1980, Venturini 1990, Schönlaub \& Forke 2007) and by extensional as well as compressional and transpressional Alpine phases (Venturini 1990, Läufer 1996), which formed a fold and thrust belt. Despite the severe deformation, the succession is mostly non-metamorphic (Brime et al. 2008).

The lithostratigraphy of the Pre-Variscan sequence was recently revised (Corradini \& Suttner 2015), and 36 formations have been discriminated. Seven of those are present in the Lochkovian: Alticola Fm., Seekopf Fm., Rauchkofel 


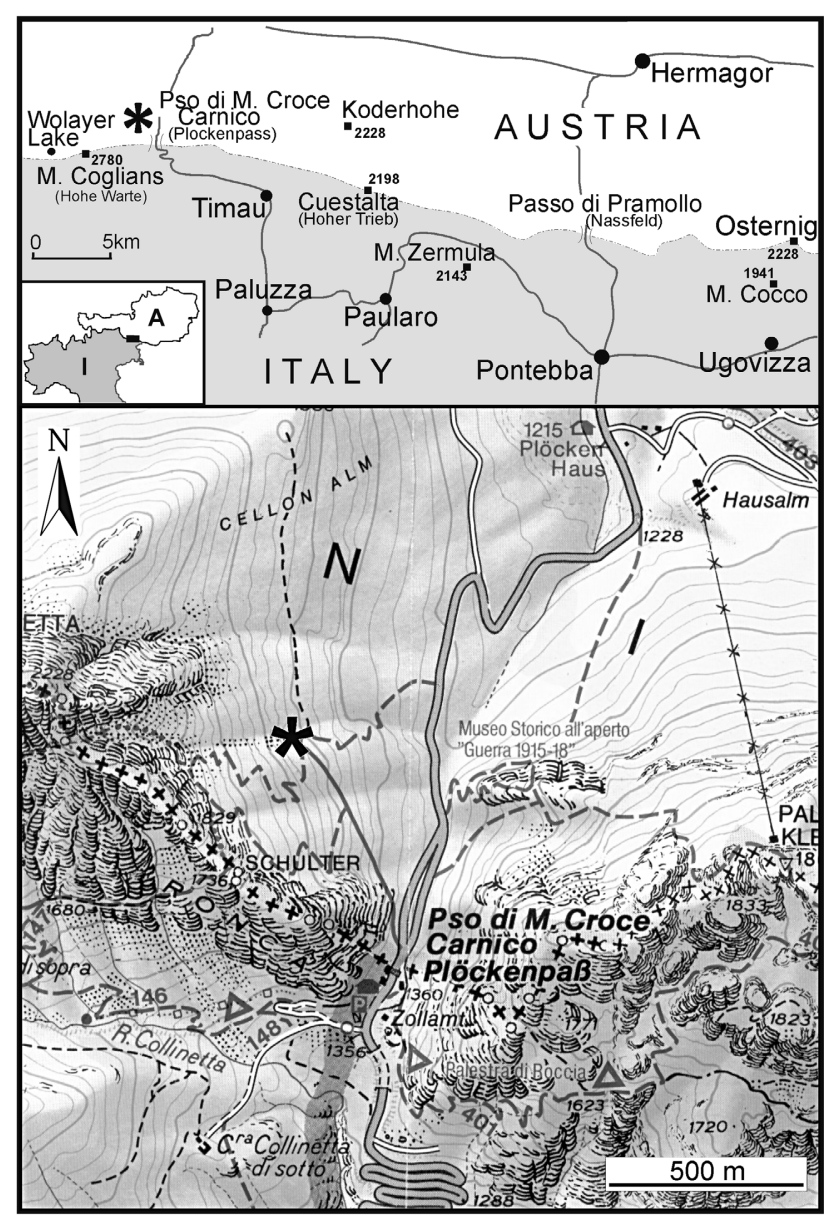

Figure 1. Location map of the Cellon section (asterisk).

Fm., La Valute Fm., Findenig Fm., Nölbling Fm. and Bischofalm Fm. (Fig. 2). These units are here briefly introduced: for a detailed description refer to Corradini \& Suttner (2015).

The Alticola Fm. (Ferretti et al. 2015c) consists of well-bedded cephalopod bearing wackestone to packstone of Ludlow-lowermost Lochkovian age. The Silurian/Devonian boundary lies in the uppermost part of the unit, very close to its top.

The Seekopf Fm. (Suttner et al. 2015) consists of a mostly greyish very shallow water lithoclastic limestone with abundant fossil debris, of Př́idolí-early Pragian age.

The Rauchkofel Fm. (Corradini et al. 2015c) consists of mainy laminated dark grey well-bedded platy mudstone to wackestone with intercalation of black shales and marls, and locally conglomerates, of Lochkovian age.

The La Valute Fm. (Corradini et al. 2015b) consists of light grey/ocraceus cephalopod mudstone to wackestone, slightly nodular in the upper part. Its age is comprised between the upper part of the lower Lochkovian and the upper Lochkovian.

The Nölbling Fm. (Schönlaub et al. 2015a) consists

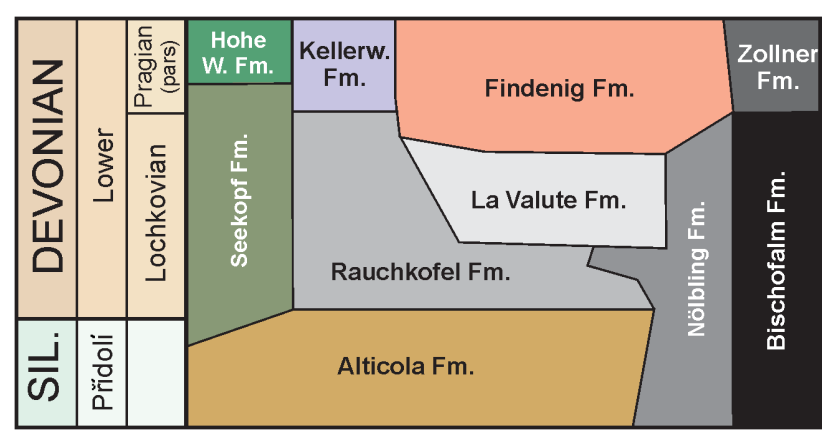

Figure 2. Stratigraphic scheme of the Lochkovian of the Carnic Alps. Abbreviations: Sil. - Silurian; Hohe W. - Hohe Warte; Kellerw. Kellerwand.

mainly of black shales with nodules and layers of dark cephalopod wackestone to mudstone. Its age spans from lower Silurian to the end of Lochkovian.

The Bischofalm Fm. (Schönlaub et al. 2015b) consists of black siliceous and alum shale of Silurian to Lochkovian age.

The Findenig Fm. (Spalletta et al. 2015) consists of distinct reddish nodular mudstone to wackestone of late Lochkovian-Eifelian age.

\section{The Cellon section}

The Cellon section is located in a narrow avalanche gorge on the eastern flank of Mt. Cellon, at an altitude of about $1500 \mathrm{~m}$, at coordinates $46^{\circ} 36^{\prime} 32^{\prime \prime} \mathrm{N}, 12^{\circ} 56^{\prime} 31^{\prime \prime} \mathrm{E}$, close to the Austrian/Italian border. It is accessible by a short walk from Plöcken Pass/Passo di Monte Croce Carnico (Figs 1, 3).

It probably represents the most famous Silurian section in the world, and is the reference section for many Ordovician and Silurian studies. The section has been famous since 1894, when Geyer (1894) first described the rock succession exposed here. The conodont fauna from the section was studied and described by Walliser $(1957,1964)$, whose pioneering work on the section included the first proposed Silurian conodont zonation (Walliser 1964). Subsequent studies on the Cellon section have documented the composition and distribution of several fossil groups (bivalves, brachiopods, nautiloids, graptolites, foraminifers, ostracods, acritarchs, chitinozoans, trilobites and corals), microfacies, isotope signatures, taphonomic and palaeoenvironmental indicators and eustatic sea-level changes (Schönlaub \& Lammerhuber 2009). For a complete review of the previous studies on the Cellon section, and a revision of the Silurian conodont biostratigraphy, refer to Corradini et al. (2015a).

The section exposes rocks from the Upper Ordovician to the Lower Devonian belonging to six lithostratigraphic 

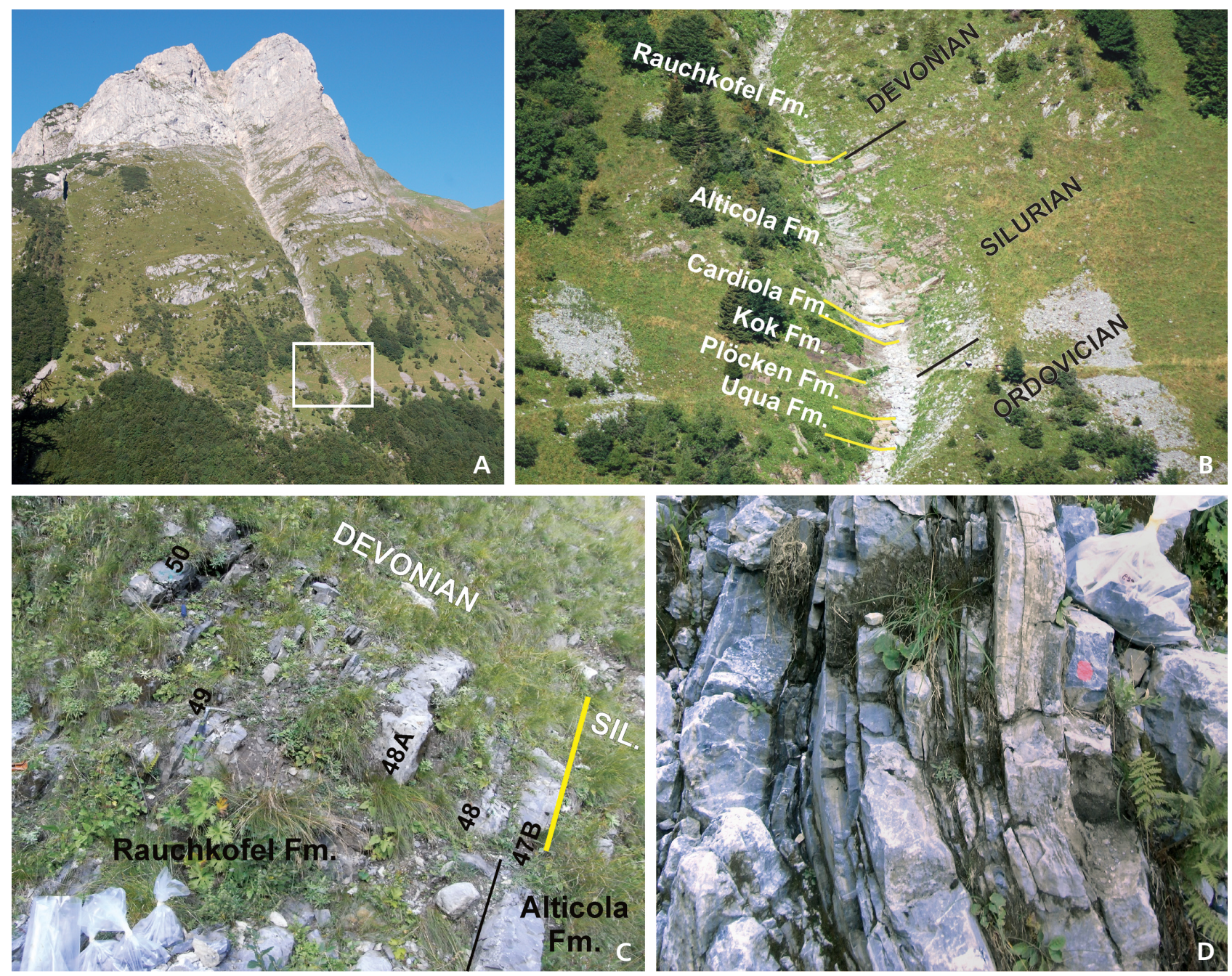

Figure 3. Views of the Cellon section. $\bullet$ A - panoramic view to the west of Mt. Cellon/Creta di Collinetta. $\bullet$ B - detail of the Cellon section (box in fig. A), with indication of the lithostratigraphic and chronostratigraphic units. $\bullet \mathrm{C}$ - detail across the Silurian/Devonian boundary, with indication of samples, and lithostratigraphic and chronostratigraphic units. $\bullet$ D - view of the Rauchkofel Fm. in the upper part of the measured section, close to sample 59.

units (Fig. 3B): Uqua Fm. (Schönlaub \& Ferretti 2015a), Plöcken Fm. (Schönlaub \& Ferretti 2015b), Kok Fm. (Ferretti et al. 2015a), Cardiola Fm. (Ferretti et al. 2015b), Alticola Fm. (Ferretti et al. 2015c) and Rauchkofel Fm. (Corradini et al. 2015c). For a detailed description of the Ordovician and Silurian parts of the section and the position of the documented chronostratigraphic boundaries refer to Histon et al. (1999) and Corradini et al. (2015a, d, and references therein).

\section{The lower Lochkovian of Cellon section}

The Silurian/Devonian boundary in the Cellon section (Fig. 4) is located in the uppermost part of the Alticola Fm., just below sample 47B (Walliser 1964, Schönlaub 1980), that yielded the first representatives of Icr. hesperius (Corradini et al. 2015a). It should be noted that the first occurrence of diagnostic graptolites of the Lochkovian are recorded about $1.5 \mathrm{~m}$ above, where Jaeger (1975) recorded the occurrences of Monograptus uniformis, M. cf. microdon and Linograptus posthumus just below sample 50; however, no graptolites have been reported from the lowermost part of the Rauchkofel Fm., so the discrepancy between conodont and graptolite data can be explained by the difficulty to find graptolites in the limestones.

The Alticola Fm. is represented by a distinctly bedded cephalopod bearing wackestone-packstone. In the uppermost beds the occurrence of bryozoans and brachiopods suggests a shallower depositional environment than the lower part (Ferretti et al. 2015c).

The formational boundary between the Alticola Fm. and the Rauchkofel Fm. is located a few centimetres above the conodont based S/D boundary, between beds 47B and 47C. The Rauchkofel Fm. mainly consists of dark grey to black laminated and well-bedded wackestone to packstone 
(and some minor thin grainstone laminae) with intercalation of black shales and marls. Chert nodules are present in a few levels. Hummocky cross stratification is observed in some thin-bedded limestone level. The packstone and grainstone beds and laminae consist of generally fine to medium grained clasts and are poorly sorted. A thick grainstone bed occurs about $4 \mathrm{~m}$ above the base of the unit. It consists of medium-grained, locally coarse grained, well-sorted material with no evidence, at the macro-scale, of sedimentary structures, and may represent a shallower depositional episode. Beside nautiloid cephalopods and graptolites, the Rauchkofel Fm. at Cellon section yields acritarchs (Priewalder 1987), chitinozoans (Priewalder 1999) and scyphocrinoid crinoids (R. Haude, pers. comm. in Histon et al. 1999).

\section{Material}

This paper is based on the revision of Walliser conodonts collection carried out during two research visits by MGC and $\mathrm{CC}$ to Göttingen University and some new samples.

The Walliser conodont collection from the Cellon section includes about 35,000 conodont elements from about 220 samples from the Upper Ordovician to the lowermost Devonian. It is archived in the Geoscience Centre of the Georg-August University of Göttingen, Germany, under repository number GZG 1613 . The Lochkovian part of the collection is limited to a few samples, from 47B to 52 . However, samples 51 and 52 were not included in Walliser (1964) monograph, but we found these unpublished samples together with indication of their precise position while studying the Walliser collection in Göttingen.

We integrate Walliser's data with several samples collected up to 18 meters above the Silurian/Devonian boundary, both resampling the some levels of Walliser and picking new ones. While sampling we continued the original numbering by Walliser (1964) above its published section. It results that numbers 51 and 52 were doubled: therefore in this paper the youngest samples by Walliser are renamed $51 \mathrm{~W}$ and 52W, respectively. Our samples from Cellon section are stored in the Palaeontological and Geological museum "Domenico Lovisato" of Cagliari University (MDLCA).

\section{Conodont fauna}

Twenty-two conodont taxa (species and subspecies), belonging to nine genera have been recognized from the Lochkovian of the Cellon section (Fig. 4).

The conodont fauna is generally well preserved. The abundance is lower in the Devonian than in the Silurian part of the section. However we do not have precise infor- mation on the weight of Walliser's samples stored in Göttingen, and therefore we cannot be more precise. In our samples the abundance is very variable from nothing (sample 57) to 37.3 conodonts per $\mathrm{kg}$ (sample 56), with an average of about 15 conodonts per $\mathrm{kg}$. In general conodonts from the lower part of the Rauchkofel Fm. are more abundant than above.

Wurmiella, that is the most abundant genus in the Silurian, becomes rarer in the Lower Devonian part of the section. Zieglerodina increases its abundance and is the dominant genus in the upper part. Icriodus is present in the lowermost Lochkovian beds, up to sample $52 \mathrm{~W}$, beside the single occurrence of a specimen of Icr. cf. transiens in sample 56. Coniform elements, almost always present, represent a minor part of the association. Other genera are very rare.

\section{Chronobiostratigraphy}

The Přídolí-Lochkovian conodont zonation provided by Corradini \& Corriga (2012) for the Carnic Alps is updated in this paper. Corradini \& Corriga (2012) discriminated in the lower Lochkovian only the Icr. hesperius Zone, indicating in its upper part the Icr. postwoschmidti Subzone. In this paper the latter interval is considered at zonal rank. Therefore two zones are distinguished in the lower Lochkovian: the Icr. hesperius Zone and the Icr. postwoschmidti Zone.

The Silurian/Devonian boundary is located at the base of sample 47B, from where Icr. hesperius has been recovered (Corradini et al. 2015a). In the uppermost Silurian beds the well-known sequence of first and last occurrences of taxa documented in other sections from the Carnic Alps (Corradini \& Corriga 2010, 2012) is present here as well: last occurrence of $\mathrm{Oz}$. confluens (sample 46), immediately followed by the entry of $Z$. remscheidensis (sample 46A), and by the last occurrence of Z. zellmeri (sample 47A), just below the S/D boundary.

The lowermost Devonian beds are attributed to the Icr. hesperius Zone. Icr. woschmidti enters just above the base of the Zone, in sample 47C. Conodont abundance and diversity is higher in the lower part of the zone, than in the upper part.

The lower boundary of the succeeding Icr. postwoschmidti Zone can be tentatively traced below sample 55, where Lanea omoalpha and Wurmiella wurmi are present: according to Corradini \& Corriga (2012) these species have their first appearance within this zone.

\section{Systematic palaeontology}

Systematic notes are limited to necessary taxonomic remarks and to taxa newly reported from the Carnic Alps. For 


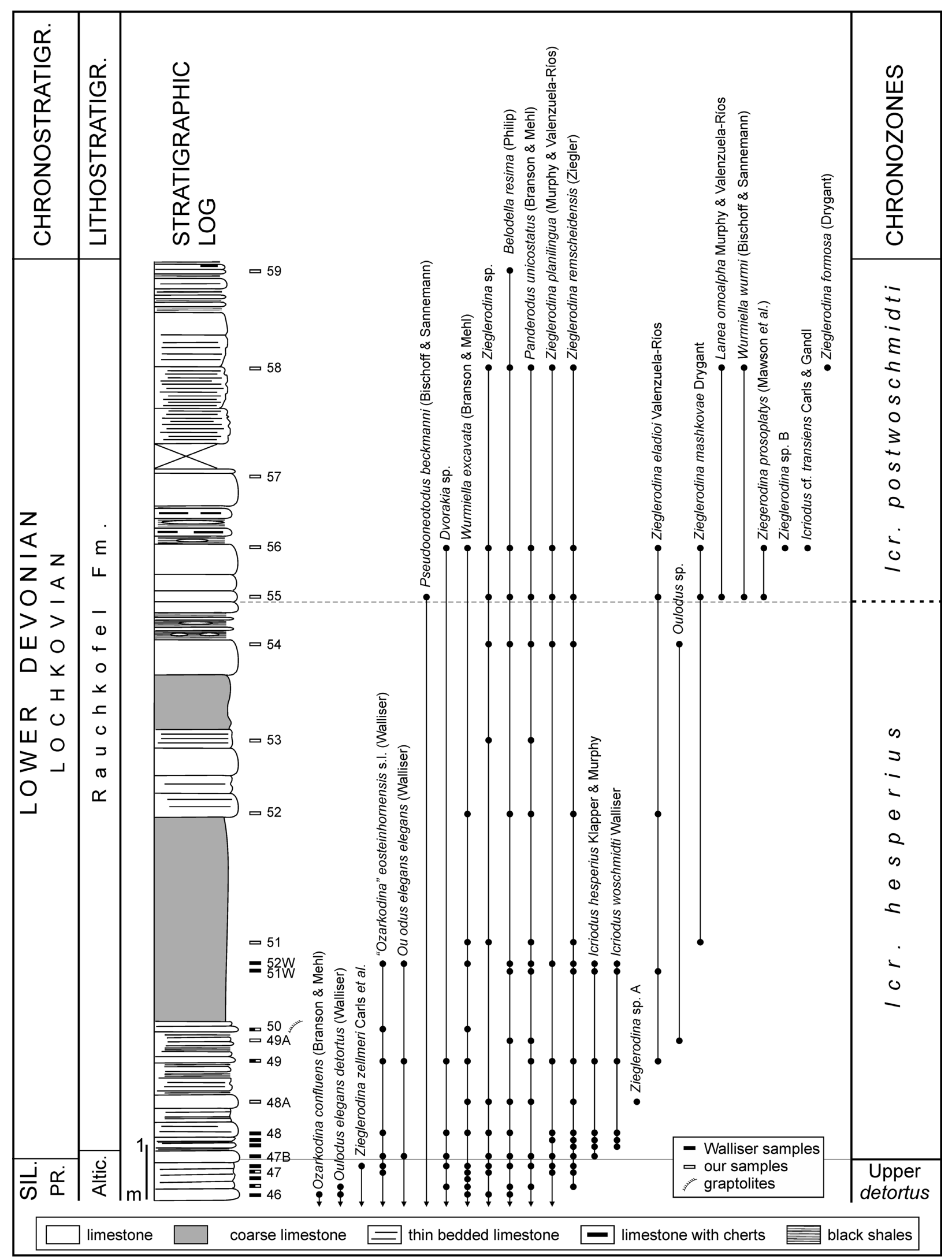

Figure 4. Stratigraphic log of the Lochkovian of the Cellon section and occurrences of conodonts. The uppermost Silurian beds (after Corradini et al. 2015a) are included to show the conodont distribution across the Silurian/Devonian boundary. Abbreviations: Sil. - Silurian; Pr. - Př́ídolí; Altic. - Alticola Fm. 
suprageneric classification the scheme proposed by Sweet (1988) is followed. Synonymy lists are limited to main captions and previous illustrations from the Carnic Alps. Descriptions and remarks are restricted to $\mathrm{P} 1$ element.

Class Conodonta Pander, 1856

Order Ozarkodinida Dzik, 1976

Family Spathognathodontidae Hass, 1959

\section{Genus Zieglerodina Murphy, Valenzuela-Ríos \& Carls, 2004}

Type species. - Spathognathodus remscheidensis Ziegler, 1960.

Remarks. - Genus Zieglerodina was estabished by Murphy et al. (2004) to include the ozarkodinids of the "remscheidensis Group"; it includes several different forms previously put together in only one species (Ozarkodina remscheidensis Ziegler). In their revision Murphy et al. (2004) restricted the diagnosis of $Z$. remscheidensis to morphs very similar to the holotype of Ziegler (1960, pl. 13, fig. 4).

Carls et al. (2007) introduced three new species to discriminate forms from the Přídolí (Z. klonkensis, Z. ivochlupaci and Z.? zellmeri). Drygant (2010) described Z. podolica, and moved Ozarkodina mashkovae Drygant, Oz. serrula Drygant and "Oz." planilingua Murphy \& Valenzuela-Ríos to Ziglerodina. The assignment of the latter species to Zieglerodina has been confirmed by Corriga et al. (2014) on the basis of the reconstruction of the apparatus. Corriga (2011) considered Ozarkodina eladioi (Valenzuela-Ríos) as a species of Zieglerodina. Later, Drygant \& Szaniawski (2012) moved $O z$. prosoplatys Mawson et al. and Oz. paucidentata (Murphy \& Matti) to the genus Zieglerodina. In the present manuscript we moved Pandorinellina formosa Drygant to the genus Zieglerodina. However, it should be noted that the generic attribution of all the species mentioned above would be confirmed only when the complete apparatuses are reconstructed.

Beside all these species, several other P1 elements show typical features of Zieglerodina but do not agree with any description. In Fig. 5N, P, R we figure some of these elements, that we leave in open nomenclature. As soon as we obtain enough material we may propose new species.

Taxa of the "eosteinhornensis Group", that Murphy et al. (2004) placed in a different genus, still not defined according to the ICZN code, have a very similar morphology of all the apparatus elements. The opportunity to establish two different genera very similar, or to place the two groups together in the same genus should be carefully evaluated.

\section{Zieglerodina eladioi (Valenzuela-Ríos, 1994)}

Figure 5A, B

1980 Ozarkodina remscheidensis remscheidensis (Ziegler). - Schönlaub, pl. 1, fig. 20/29; pl. 3, fig. 20.

1980 Ozarkodina remscheidensis eosteinhornensis (Walliser). - Schönlaub, pl. 3, fig. 13.

1985 Ozarkodina remscheidensis remscheidensis (Ziegler). - Schönlaub, pl. 1, fig. 20.

1994 Ozarkodina eladioi n. sp.; Valenzuela-Ríos, pp. 59-63, pl. 5, figs 1-35.

2011 Zieglerodina eladioi (Valenzuela-Ríos). - Corriga, p. 123, pl. 6, fig. 2; pl. 11, fig. 4.

2012 Zieglerodina eladioi (Valenzuela-Ríos). - Corriga et al., fig. 5.1.

Material. - Five specimens from samples 49, 52, 55 and 56.

Remarks. - Zieglerodina eladioi is characterized by a short blade bearing denticles of slightly variable size; the anterior part is longer than the posterior; the cusp may be slightly bigger than the other denticles.

The species differs from $Z$. remscheidensis by the generally smaller size and the shape of the denticles; it can be distinguished from $Z$. mashkovae by the smaller cusp and the irregular denticulation.

Occurrence. - From the uppermost Přídolí to the middle Lochkovian: from the upper part of the Upper Oul. el. detortus Zone to the Ad. trigonicus Zone (Corradini \& Corriga 2012).

\section{Zieglerodina formosa (Drygant, 2010)}

Figure 5M

2010 Pandorinellina formosa nov. sp.; Drygant, p. 54, pl. 1, fig. 25.

2012 ?Pandorinellina formosa Drygant. - Drygant \& Szaniawski, p. 856, fig. 12k, m, n, p, r (cum syn.).

Material. - One specimen from sample 58.

Remarks. - Zieglerodina formosa is characterized by a sigmoidal lower margin of the element, that is curved upward in the anterior part, and downward in the posterior. Three or four denticles close to the anterior part of the element are higher than the others, while the cusp is only slightly larger than the adjacent denticles.

Drygant (2010) assigned the species to Pandorinellina, whereas Drygant \& Szaniawski (2012) maintained the attribution, but dubitatively. However, they discussed similarity with $Z$. remscheidensis, and indicated the latter taxon 


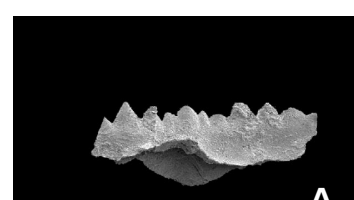

A

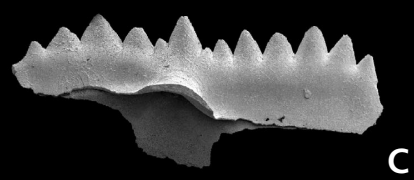

C

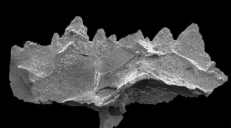

B

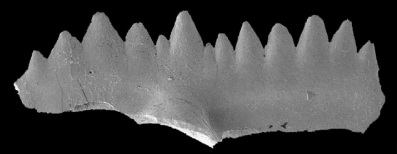

D

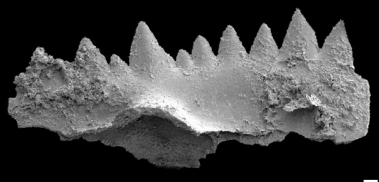

F

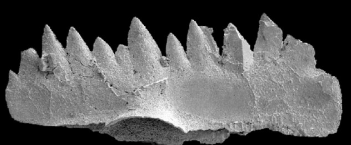

H
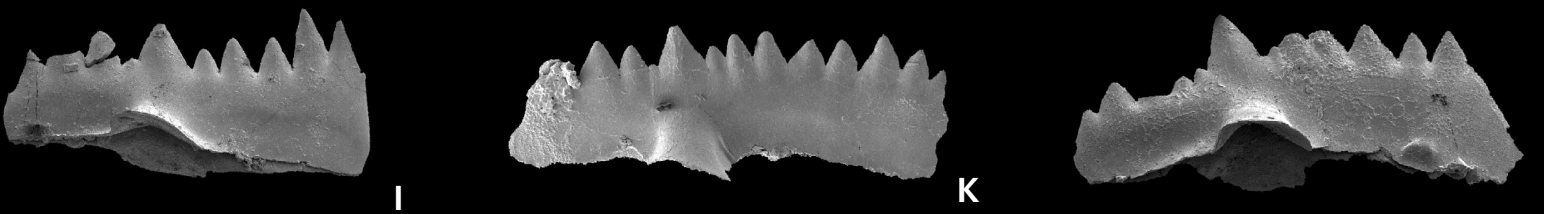

L
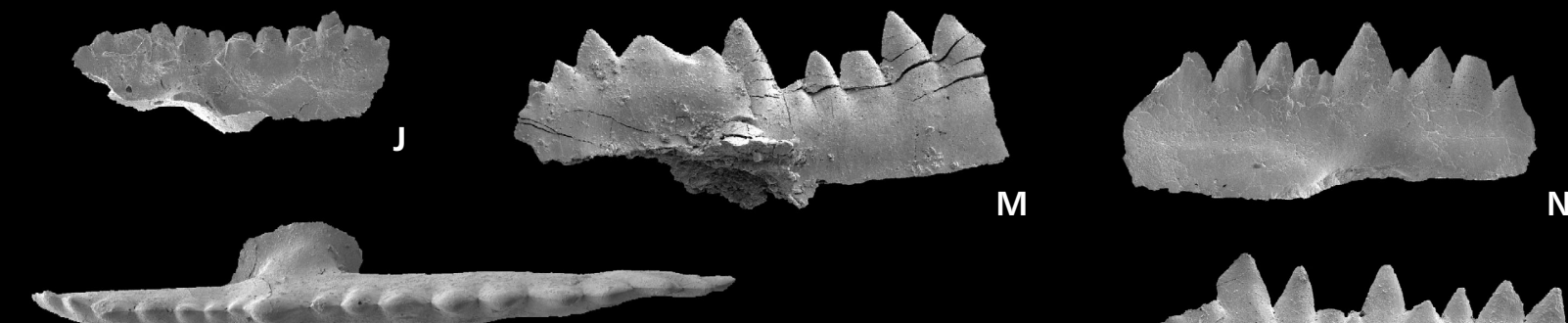

M

N
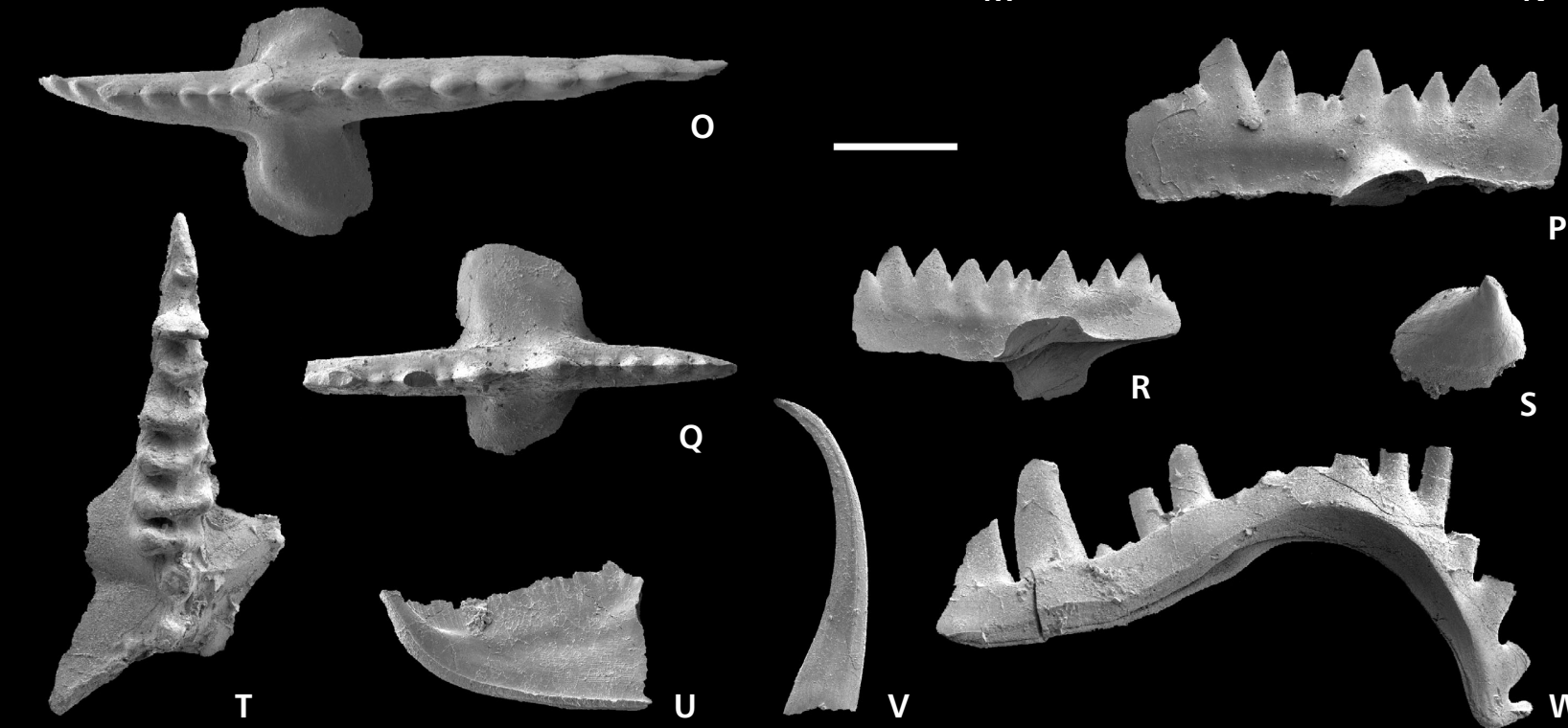

Q
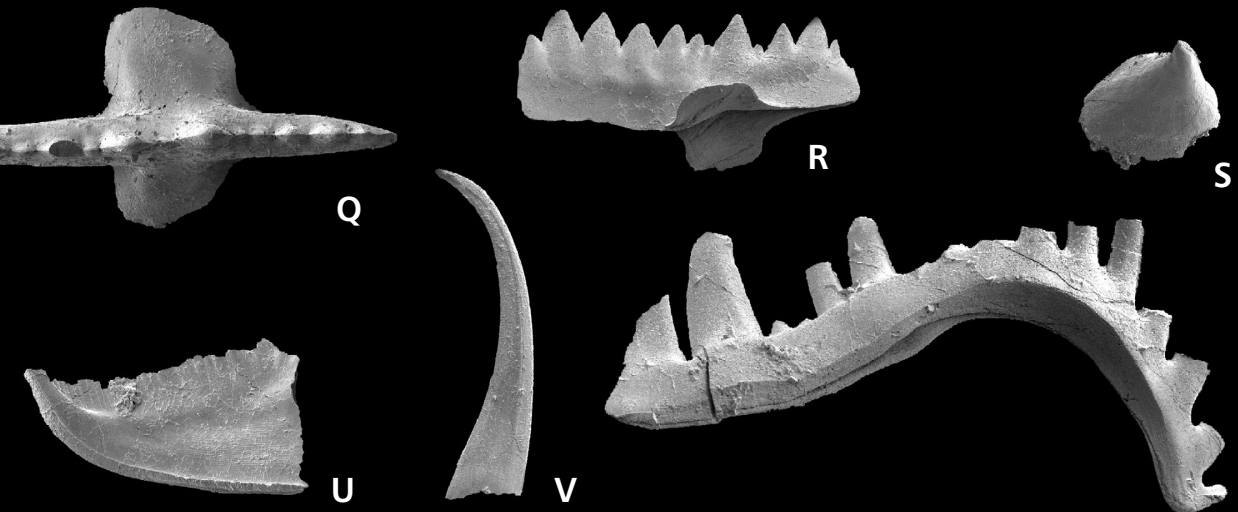

P

Figure 5. Conodonts from the Lochkovian of Cellon section. • A - Zieglerodina eladioi (Valenzuela-Ríos, 1994), lateral view of P1 element MDLCA 30333, sample 52. • B - Zieglerodina eladioi (Valenzuela-Ríos, 1994), lateral view of P1 element MDLCA 30334, sample 52. • C, D - Zieglerodina mashkovae (Drygant, 1984), lower-lateral and lateral views of P1 element MDLCA 30335, sample 56.・E-Zieglerodina mashkovae (Drygant, 1984), lateral view of P1 element MDLCA 30336, sample 56. $\bullet \mathrm{F}-$ Zieglerodina sp. B, lateral view of P1 element MDLCA 30337, sample 56. $\bullet \mathrm{G}-$ Zieglerodina sp. A, lateral view of P1 element MDLCA 30338, sample 48A. $\bullet \mathrm{H}-$ Zieglerodina sp. A, lateral view of P1 element MDLCA 30339, sample 48A. $\bullet$ I - Zieglerodina remscheidensis (Ziegler, 1960), lateral view of P1 element MDLCA 30340, sample 55. • J - Zieglerodina remscheidensis (Ziegler, 1960), lateral view of P1 element MDLCA 30341, sample 51. $-\mathrm{K}$ - Zieglerodina prosoplatys (Mawson et al., 2003), lateral view of P1 element MDLCA 30342 , sample 56. $\cdot \mathrm{L}$ - Zieglerodina prosoplatys (Mawson et al., 2003), lateral view of P1 element MDLCA 30343, sample 55. • M - Zieglerodina formosa (Drygant, 2010), lateral view of P1 element MDLCA 30344, sample 58. $\bullet \mathrm{N}$ - Zieglerodina sp., lateral view of P1 element MDLCA 30345, sample 56. $\bullet$ - Zieglerodina planilingua (Murphy \& Valenzuela-Ríos, 1999), upper view of P1 element MDLCA 30348, sample 55. • P - Zieglerodina sp., lateral view of P1 element MDLCA 30346, sample 55. • Q - Lanea omoalpha Murphy \& Valenzuela-Ríos, 1999, upper view of P1 element MDLCA 30349 , sample 55. $\cdot \mathrm{R}$ - Zieglerodina sp., lateral view of P1 element MDLCA 30347, sample 56. $\bullet \mathrm{S}-$ Pseudooneotodus beckmanni (Bischoff \& Sannemann, 1958), upper-lateral view of element MDLCA 30350, sample 55. $\bullet$ T - Icriodus hesperius Klapper \& Murphy, 1975, upper view of P1 element MDLCA 30351, sample 49. -U - Belodella resima (Philip, 1965), lateral view of P1 element MDLCA 30352, sample 55. $\bullet \mathrm{V}$ - Panderodus unicostatus (Branson \& Mehl, 1933), lateral view of element MDLCA 30353, sample 55. • W - Oulodus sp., lateral view of S1 element MDLCA 30354, sample 54. 
as related, differing only by the shape of the lower margin of the element. Considering this strong similarity, and awaiting the reconstruction of the apparatus, we prefer to consider this species belonging to Zieglerodina. In fact, differences between Zieglerodina and Pandorinellina are based on the morphology of ramiform elements.

Occurrence. - Lower and middle Lochkovian (Drygant \& Szaniawski 2012).

\section{Zieglerodina mashkovae (Drygant, 1984)}

Figure 5C-E

1984 Spathognathodus mashkovae sp. n.; Drygant, p. 125, pl. 14, fig. 10, 11, 13-21.

? 1980 Ozarkodina remscheidensis remscheidensis (Ziegler). - Schönlaub, pl. 1, fig. 10/20.

? 1985 Ozarkodina remscheidensis remscheidensis (Ziegler). - Schönlaub, pl. 1, fig. 10.

2010 Zieglerodina mashkovae (Drygant). - Drygant, p. 53, pl. 1, figs 18-20.

2012 Zieglerodina mashkovae (Drygant). - Drygant \& Szaniawski, p. 854, fig. 12u, 13g, k.

Material. - Five specimens from sample 51, 55 and 56.

Remarks. - Zieglerodina mashkovae is characterized by straight upper and lower margins of the element, a high cusp definitely bigger that the other denticles that are more or less of equal height, and a symmetrical basal cavity approximately in central position.

Drygant (2010) suggested that Z. eladioi (Valenzuela-Ríos) could be a junior synonym of Z. mashkovae, but we disregard this assignment, because of distinct differences in the P1 element, and we consider Z. eladioi as a valid species. For description of the latter see above.

Occurrence. - According to Drygant \& Szaniawski (2012) the species occurs in the whole Lochkovian, from the Caud. hesperius Zone to the Caud. serus Zone in Podolia, whereas in other regions it is limited to lower and middle Lochkovian.

\section{Zieglerodina prosoplatys (Mawson et al., 2003)} Figure 5K, L

2003 Ozarkodina remscheidensis prosoplatys Mawson et al., p. 92, pl. 1, figs 4-23.

2012 Zieglerodina prosoplatys (Mawson et al.). - Drygant \& Szaniawski, p. 854, fig. 13e, f, j.

Material. - Two specimens from samples 55 and 56.
Remarks. - Zieglerodina prosoplatys is characterized by a slightly bowed concave basal margin and an anterior deepening of the blade.

Occurrence. - Lower Lochkovian. Mawson et al. (2003) reported the species from the Icr. hesperius Zone into the Icr. eurekaensis Zone in Pakistan. The latter Zone is more or less equivalent to the Icr. postwoschmidti Zone and the lower part of the Ad. carlsi Zone of present schemes (Corradini \& Corriga 2012). Our specimens from Cellon section come from the Icr. postwoschmidti Zone.

\section{Zieglerodina sp. A}

Figure 5G, H

2010 Zieglerodina remscheidensis (Ziegler). - Drygant, pl. 1, fig. 3 (only).

Material. - Four specimens from sample 48A.

Description. - P1 element of Zieglerodina characterized by a short blade bearing closely spaced denticles of different size on both processes, with smaller denticles intercalated within larger ones. The cusp is slightly larger than the other denticles and is located in central position, above the small basal cavity.

Remarks. - The species differs from other taxa of Zieglerodina for the alternate denticulation pattern and the parallel lower and upper margin of the blade.

Occurrence. - Lower Lochkovian, Icr. hesperius Zone.

\section{Zieglerodina sp. B}

Figure 5F

1980 Ozarkodina remscheidensis remscheidensis (Ziegler). - Schönlaub, pl. 2, fig. 1/32; pl. 6, fig. 7.

1985 Ozarkodina remscheidensis remscheidensis (Ziegler). - Schönlaub, pl. 2, fig. 1.

Material. - Three specimens from sample 56.

Description. - P1 element of Zieglerodina characterized by a strong blade, higher in the anterior part, that bears strong triangular denticles, that have an alternate pattern on the posterior part; in the anterior part the size of denticles decreases from the distal end towards the cusp, with the exception of the last denticle that is slightly smaller than the adjacent one. The cusp, triangular in lateral view, is larger than the denticles. The wide, asymmetrical, basal cavity is located about $1 / 3$ of the length of the element. 
Remarks. - The characteristic pattern of the denticles distinguishes this taxon from the other species of Zieglerodina.

Occurrence. - Lower Lochkovian, Icr. postwoschmidti Zone.

\section{Conclusions}

The main results of this study on the Lochkovian part of Cellon section can be summarized as follows:

(i) Twenty-two conodont taxa (species and subspecies) have been recognized, belonging to nine genera (Belodella, Dvorakia, Icriodus, Lanea, Oulodus, Ozarkodina, Panderodus, Wurmiella and Zieglerodina);

(ii) Zieglerodina formosa, Z. mashkovae and Z. prosoplatys are reported for the first time from the Carnic Alps; two other species of Zieglerodina, probably new, are described in open nomenclature.

(iii) The investigated part of the section can be assigned to the lower Lochkovian (Icriodus hesperius and Icr. postwoschmidti conodont zones).

\section{Acknowledgements}

Helga Groos-Uffenorde helped during the recent study of the Walliser conoodont collection, giving support during our recent visits to the Geoscience Centre of the Georg-August University of Göttingen. SEM micrographs were taken by Elodia Musu at CRS4. Thomas Suttner and Nacho Valenzuela-Ríos provided useful comments to the manuscript. Research by CC and MGC was partly supported by grants RAS and PRID (resp. C. Corradini). This paper is a contribution to IGCP Project 596 Climate change and biodiversity patterns in the Mid-Paleozoic.

\section{References}

Bischoff, G. \& Sannemann, D. 1958. Unterdevonische Conodonten aus dem Frankenwald. Notizblatt des Hessischen Landesamtes für Bodenforschung 86, 87-110.

Branson, E.B. \& Mehl, M.G. 1933. Conodonts from the Bainbridge Formation (Silurian) of Missouri. University of Missouri Studies 8, 39-52.

Brime, C., Perri, M.C., Pondrelli, M., Spalletta, C. \& VenTURINI, C. 2008. Polyphase metamorphism in the eastern Carnic Alps (N Italy-S Austria): clay minerals and conodont Colour Alteration Index evidence. International Journal of Earth Science 97, 1213-1229. DOI 10.1007/s00531-007-0218-7

Carls, P., SLavíK, L. \& ValenZuela-Ríos, J.I. 2007. Revisions of conodont biostratigraphy across the Silurian-Devonian boundary. Bulletin of Geosciences 82(2), 145-164. DOI 10.3140/bull.geosci.2007.02.145

Corradini, C. \& Corriga, M.G. 2010. Silurian and lowermost
Devonian conodonts from the Passo Volaia area (Carnic Alps, Italy). Bollettino della Società Paleontologica Italiana 49(3), 237-253.

Corradini, C. \& Corriga, M.G. 2012. A Přídolí-Lochkovian conodont zonation in Sardinia and the Carnic Alps: implications for a global zonation scheme. Bulletin of Geosciences 87(4), 635-650. DOI 10.3140/bull.geosci.1304

Corradini, C., Corriga, M.G., Männik, P. \& Schönlaub, H.P. 2015a. Revised conodont stratigraphy of the Cellon section (Silurian, Carnic Alps). Lethaia 48, 56-71. DOI 10.1111/let.12087

Corradini, C., Corriga, M.G., Pondrelli, M., Schönlaub, H.P. \& SimonetTo, L. 2015b. La Valute Formation, 77-80. In Corradini, C. \& Suttner, T. (eds) The Pre-Variscan sequence of the Carnic Alps (Austria and Italy). Abhandlungen der Geologischen Bundesanstalt 69.

Corradini, C., Corriga, M.G., Pondrelli, M., Schönlaub, H.P., Simonetto, L., Spalletta, C. \& Ferretti, A. 2015c. Rauchkofel Formation, 73-76. In Corradini, C. \& SutTner, T. (eds) The Pre-Variscan sequence of the Carnic Alps (Austria and Italy). Abhandlungen der Geologischen Bundesanstalt 69.

Corradini, C., Pondrelli, M., Suttner, T.J. \& Schönlaub, H.P. 2015d. The Pre-Variscan sequence of the Carnic Alps. Berichte der Geologischen Bundesanstalt 111, 5-40.

Corradini, C. \& Suttner, T. (eds) 2015. The Pre-Variscan sequence of the Carnic Alps (Austria and Italy). Abhandlungen der Geologischen Bundesanstalt 69, 1-158.

Corriga, M.G. 2011. Biostratigrafia a conodonti attorno al limite Siluriano-Devoniano in alcune aree del Nord Gondwana. $174 \mathrm{pp}$. $\mathrm{PhD}$ thesis, Università di Cagliari.

Corriga, M.G., Corradini, C., Pondrelli, M. \& Simonetto, L. 2012. Lochkovian (Lower Devonian) conodonts from the Rio Malinfier section (Carnic Alps, Italy). Gortania Geologia, Paleontologia, Paletnologia 33, 31-38.

Corriga, M.G., Corradini, C. \& Walliser, O.H. 2014. Upper Silurian and Lower Devonian conodonts from Tafilalt, southeastern Morocco. Bulletin of Geosciences 89(1), 183-200. DOI 10.3140/bull.geosci.1473

DRYGANT, D.M. 1984. Correlation and conodonts from the Silurian-Lower Devonian deposits of the Volyno-Podolian. 192 pp. Naukova dumka, Kiev. [in Russian]

Drygant, D.M. 2010. Devonian conodonts from South-West Margin of the East European Platform (Volyn'-Podolian Ukraine). 156 pp. Academperiodyka, Kyiv. [in Ukrainian]

Drygant, D. \& Szaniawski, H. 2012. Lochkovian conodonts from Podolia, Ukraine and their stratigraphic significance. Acta Palaeontologica Polonica 57(4), 833-861. DOI 10.4202/app.2012.0124

DzIK, J. 1976. Remarks on the evolution of Ordovician conodonts. Acta Palaeontologica Polonica 21, 395-455.

FerRetti, A. \& Schönlaub, H.P. 2001. New conodont faunas from the Late Ordovician of the Central Carnic Alps, Austria. Bollettino della Società Paleontologica Italiana 40, 3-15.

Ferretti, A., Schönlaub, H.P., Corradini, C., Corriga, M.G., Pondrelli, M., Simonetto, L. \& Serventi, P. 2015a. Kok Formation, 46-51. In Corradini, C. \& SutTner, T. (eds) The Pre-Variscan sequence of the Carnic Alps (Austria and Italy). Abhandlungen der Geologischen Bundesanstalt 69.

Ferretti, A., Schönlaub, H.P., Corradini, C., Corriga, M.G., Pondrelli, M., Simonetto, L. \& Serventi, P. 2015b. Cardiola Formation, 52-55. In CoRradini, C. \& SutTner, T. (eds) The Pre-Variscan sequence of the Carnic Alps (Austria and Italy). Abhandlungen der Geologischen Bundesanstalt 69. 
Ferretti, A., Schönlaub, H.P., Corradini, C., Corriga, M.G., Pondrelli, M., Simonetto, L. \& Serventi, P. 2015c. Alticola Formation, 56-60. In CoRRAdini, C. \& SutTnER, T. (eds) The Pre-Variscan sequence of the Carnic Alps (Austria and Italy). Abhandlungen der Geologischen Bundesanstalt 69.

GEYER, G. 1894. Zur Stratigraphie der palaeozoischen Schichtserie in den Karnischen Alpen. Verhandlungen der Kaiserlich-königlichen geologischen Reichsanstalt 1894, 102-119.

Hass, W.H. 1959. Conodonts from the Chappel Limestone of Texas. U.S. Geological Survey Professional Paper 294, 365-399.

Histon, K., Ferretti, A. \& SchÖnlaub, H.P. 1999. The Palaeozoic of the Southern Alps, 6-30. In Histon, K. (ed.) V International Symposium, Cephalopods - Present and Past, Carnic Alps Excursion Guidebook. Berichte der Geologischen Bundesanstalt 47.

JAEGER, H. 1975. Die Graptolithenführung im Silur/Devon des Cellon-Profils (Karnische Alpen). Carinthia II 165, 111-126.

KLAPPER, G. \& MurPhy, M.A. 1975. Silurian-Lower Devonian conodont sequence in the Roberts Mountains Formation of central Nevada. University of California Publications in Geological Sciences 111, 1-62.

LÄUFER, A.L. 1996. Variscan and Alpine tectonometamorphic evolution of the Carnic Alps (Southern Alps) - structural analysis, illite cristallinity, K-Ar and Ar-Ar geochronology. Tübingen Geowissenschaftliche Arbeiten A26, 1-101.

Mawson, R., Talent, J.A., Molloy, P. \& Simpson, A.J. 2003. Siluro-Devonian (Pridoli-Lochkovian and early Emsian) conodonts from the Nowshera area, Pakistan: implications for the mid-Palaeozoic stratigraphy of the Peshawar Basin. Courier Forschungsinstitut Senckenberg 245, 83-105.

Murphy, M.A. \& VAlenzuela-Ríos, J.I. 1999. Lanea new genus, lineage of Early Devonian conodonts. Bollettino della Società Paleontologica Italiana 37, 321-334.

Murphy, M.A., Valenzuela-Ríos, J.I. \& Carls, P. 2004. On Classification of Pridoli (Silurian)-Lochkovian (Devonian) Spathognathodontidae (Conodonts). University of California, Riverside Campus Museum Contribution 6, 1-25.

PANDER, C.H. 1856. Monographie der fossilen Fische des Silurischen System der Russisch-Baltischen Gouvernments. 83 pp. Petersburg.

PhILIP, G.M. 1965. Lower Devonian conodonts from the Tyers area, Gippsland, Victoria. Proceedings of the Royal Society of Victoria 79, 95-117.

Priewalder, H. 1987. Acritarchen aus dem Silur des CellonProfils, Karnische Alpen, Österreich. Abhandlungen der Geologischen Bundesanstalt 40, 1-121.

PRIEWALDER, H. 1999. The Chitinozoans in the upper Ordovician to lowermost Devonian succession of the Cellon-Section. A preliminary report, 31-42. In Histon, K. (ed.) V International Symposium, Cephalopods - Present and Past, Carnic Alps Excursion Guidebook. Berichte der Geologischen Bundesanstalt 47.

SchÖNLAUB, H.P. 1980. Silurian and Devonian conodont localities in the Barrandian, 5-57. In SchÖNLAUB, H.P. (ed.) Second European Conodont Symposium (ECOS II), Guidebook, Abstracts. Abhandlungen der Geologischen Bundesanstalt 35.

SchÖnlaub, H.P. 1985. Devonian conodonts from section Oberbuchach II in the Carnic Alps (Austria). Courier Forschungsinstitut Senckenberg 75, 353-374.

Schönlaub, H.P. \& Ferretti, A. 2015a. Uqua Formation, 38-41.
In Corradini, C. \& Suttner, T. (eds) The Pre-Variscan sequence of the Carnic Alps (Austria and Italy). Abhandlungen der Geologischen Bundesanstalt 69.

SchöNlaub, H.P. \& FerRetTI, A. 2015b. Plöcken Formation, 42-45. In Corradini, C. \& SutTner, T. (eds) The PreVariscan sequence of the Carnic Alps (Austria and Italy). Abhandlungen der Geologischen Bundesanstalt 69.

Schönlaub, H.P., Ferretti, A., Corradini, C., Corriga, M.G., Pondrelli, M. \& SimonetTo, L. 2015a. Nölbling Formation, 61-64. In Corradini, C. \& SutTner, T. (eds) The Pre-Variscan sequence of the Carnic Alps (Austria and Italy). Abhandlungen der Geologischen Bundesanstalt 69.

Schönlaub, H.P., Ferretti, A., Corradini, C., Corriga, M.G., Pondrelli, M. \& Simonetto, L. 2015b. Bischofalm Formation, 65-68. In Corradini, C. \& Suttner, T. (eds) The Pre-Variscan sequence of the Carnic Alps (Austria and Italy). Abhandlungen der Geologischen Bundesanstalt 69.

SCHÖNLAUB, H.P. \& ForKe, H.C. 2007. Die post-variszische Schichtfolge der Karnischen Alpen - Erläuterungen zur Geologischen Karte des Jungpaläozoikums der Karnischen Alpen 1:12.500. Abhandlungen der Geologischen Bundesanstalt $61,3-157$.

Schönlaub, H.P. \& Lammerhuber, A. 2009. Geologie und Zeit an Beispielen aus den Karnischen Alpen. 48 pp. Verlag der Geologische Bundesanstalt und Edition Lammerhuber, Wien-Baden.

Spalletta, C., Pondrelli, M., Corradini, C., Corriga, M.G., PerRi, M.C., Schönlaub, H.P., Simonetto, L. \& Mossoni, A. 2015. Findenig Formation, 129-132. In CORRADINI, C. \& SuTTNER, T. (eds) The Pre-Variscan sequence of the Carnic Alps (Austria and Italy). Abhandlungen der Geologischen Bundesanstalt 69.

Suttner, T., Bandel, K., Corradini, C., Corriga, M.G., Kido, E., Pohler, S.M.L., Pondrelli, M., Schönlaub, H.P., Simonetto, L. \& VAI, G.B. 2015. Seekopf Formation, 69-72. In Corradini, C. \& Suttner, T. (eds) The Pre-Variscan sequence of the Carnic Alps (Austria and Italy). Abhandlungen der Geologischen Bundesanstalt 69.

SweEt, W.C. 1988. The Conodonta: morphology, taxonomy, paleoecology, and evolutionary history of a long-extinct animal phylum. Oxford Monographs on Geology and Geophysics 10. 212 pp. New York.

Valenzuela-Ríos, J.I. 1994. Conodontos del Lochkoviense y Praguiense (Devónico Inferior) del Pirineo Central Español. Memorias del Museo Paleontologico de la Universidad de Zaragoza 5, 1-142.

Venturini, C. 1990. Geologia delle Alpi Carniche centroorientali. 222 pp. Comune di Udine, Museo Friulano di Storia Naturale, Pubblicazioni 36, Udine.

WALLISER, O.H. 1957. Conodonten aus dem oberen Gotlandium Deutschlands und der Karnischen Alpen. Notizblatt des Hessischen Landesamtes für Bodenforschung 85, 28-52.

Walliser, O.H. 1964. Conodonten des Silurs. Abhandlungen des Hessischen Landesamtes für Bodenforschung zu Wiesbaden 41, 1-106.

ZIEGLER, W. 1960. Conodonten aus dem Rheinischen Unterdevon (Gedinnium) des Remscheider Sattels (Rheinisches Schiefergebirge). Paläontologische Zeitschrift 34(2), 169-201. DOI 10.1007/BF02987050 